KS. JAN ZWIAZZEK

\title{
DZIEJE INSTYTUCJI DIECEZJALNYCH W CZĘSTOCHOWIE
}

\section{PRZED POWSTANIEM PARAFII}

Od pierwszej udokumentowanej wiadomości o Częstochowie upłynęło już prawie 780 lat. Dokument biskupa krakowskiego Iwo Odroważa z dnia 25 XII 1220 r. wymienił tę miejscowość jako należącą do uposażenia klasztoru Kanoników Regularnych Lateraneńskich we Mstowie ${ }^{1}$. Klasztor mstowski istniał w tej miejscowości od ostatniego dziesięciolecia XII wieku. Został wzniesiony po północnej stronie rzeki Warty, podczas gdy dotychczasowa miejscowość Mstów wraz z kościołem parafialnym była usytuowana po południowej stronie tej rzeki ${ }^{2}$. W tych okolicznościach klasztor znajdował się na terytorium archidiecezji gnieźnieńskiej, bowiem rzeka Warta była linia graniczną pomiędzy archidiecezją gnieźnieńską a diecezją krakowską, a także pomiędzy dzielnicami Wielkopolską i Małopolską ${ }^{3}$. Tymczasem północna strona rzeki w tym czasie była całkowicie nie zamieszkała, a klasztor był jedyną budowlą w tym miejscu Powstała przeto sytuacja iż bezpośrednio przy osadzie Mstów powstał klasztor, oddzielony jednak rzeką graniczną Warta. Kanonicy Regularni przy swoim klasztorze wybudowali świątynię zakonna, Tak klasztor jak i światynia zakonna były jednocześnie ściśle powiąane z miejscowością Mstów i jej mieszkańcami. Tylko zresztą dzięki tym wzajemnym powiązaniom klasztor posiadał podstawy swego istnienia. Po stronie archidiecezji gnieźnieńskiej jednocześnie nie było nie tylko żadnego ośrodka kościelnego, a w najbliższej okolicy nie było także znaczniejszego skupiska

${ }^{1}$ Pierwszy raz wymieniła miejscowość bulla pap. Celestyna III w 1193 r. jako podległa klasztorowi Kanoników Regularnych we Wrocławiu na Piasku. - Repertorium polskich dokumentów doby piastowskiej. Zeszyt 1, do końca wieku XII. Kraków 1937, s. 125.

${ }^{2}$ B. Chl e b ow ski, Mstów. W: Stownik geograficzny Królestwa Polskiego $i$ innych krajów stowiańskich. Pod red. B. Chle bowski ego, W. Wa lewski e go i F. Sulim irski eg o, t. 6, Warszawa 1885 , s. $779-780$; M. K a n t o r-M irs k i: Warowny klasztor w Mstowie, Szkic historyczny z ilustracjami, Sosnowiec 1929.

${ }^{3}$ J. Z w i ą z e k, Przynależność kościelna pogranicza Wielko- i Malopolski ze Ślaskiem. „Prace Naukowe WSP w Częstochowie. Zeszyty Historyczne”, t. 2:1994, s. 82- 83. 
ludności. W takiej sytuacji biskup krakowski Iwo Odrowąż rozumiał, iż klasztor wraz ze świątynią zakonną stanowiły istotną część Mstowa i dlatego jako swój obowiazzek uważał uposażenie klasztoru Kanoników Regularnych Lateraneńskich dziesięcinami z miejscowości należących do jego diecezji, a położonych w pobliżu Mstowa. Zresztą i mieszkańcy Mstowa ściśle wiązali wzgórze po drugiej stronie rzeki, na którym został wybudowany klasztor ze swoją osada, nie tylko bliskością położenia, ale także lokalnymi wierzeniami i legendami ${ }^{4}$.

Na początku XIII w. Mstów był największą osadą w tej okolicy, a położony przy trakcie prowadzącym z Krakowa do Wielkopolski posiadał duże możliwości rozwoju w przyszłości. Wprawdzie po stronie archidiecezji gnieźnieńskiej znajdowała się także duża osada Borzykowa, ale była ona położona w dużej odległości od Mstowa ${ }^{5}$.

Mstów w tym czasie był bez wạtpienia jedynym ośrodkiem parafialnym $\mathrm{w}$ tej okolicy. Była to parafia średniowieczna i to z czasów tworzenia się sieci parafialnej na ziemiach polskich. Istotnym zagadnieniem był problem granic parafii w końcu XII w. i na początku XIII w. Parafie w tym czasie należały do rzadkości. Granice parafii w tym czasie nie były jeszcze dokładnie wyznaczone. Okręg parafialny był zakreślony oddziaływaniem duchownego, który prowadził działalność duszpasterską w kościele grodowym lub w innym ośrodku ludzkim. Właściciel grodu angażował duchownego i sprawował ius patronatus nad świątynią. Taką była zapewne i parafia mstowska. Jej granice sięgały tam, dokąd docierał duchowny prowadzący działalność duszpasterską $\mathrm{w}$ miejscowym kościele. W granicach tak pojętej parafii znajdowała się wieś Częstochowa'.

Kanonicy Regularni Lateraneńscy, którzy przybyli do Mstowa z klasztoru we Wrocławiu na Piasku na przełomie XII i XIII stulecia założyli tu duży klasztor. Biskup Iwo Odrowąż znał ten zakon, dlatego nie tylko potwierdził jego istnienie we Mstowie, ale jednocześnie bogato go uposażył ${ }^{7}$. W ten sposób początki Częstochowy w dziedzinie kościelnej zostały związane z tym

${ }^{4}$ M. K a n to r-M irski, Warowny klasztor..., s. 6-7; E. W a rta lsk a, Dzieje Częstochówki (1220-1655). W: Częstochowa i jej miejsce w kulturze polskiej, Częstochowa 1990, s. 22.

A. J. Z a krzewski, Gmina Żytno - ziemia, ludzie, wydarzenia, „Biuletyn Instytutu Filozoficzno-Historycznego WSP w Częstochowie" R. 9/2/:1997, s. 9-10.

${ }^{6} \mathrm{~S} . \mathrm{Z}$ a ch or ow s ki, Poczatki parafii polskich. W: Studia historyczne wydane ku czci prof. Wincentego Zakrzewskiego, Kraków 1908, s. 281-292; E. W is n n i ow s k i, Rozwój slecl parafialnej $w$ prepozyturze wiślickiej $w$ średniowieczu, Warszawa 1965, s. 60-61; $\mathrm{J}$. L a be r s h ek, Rozwój sieci parafialnej $w$ dekanacie lelowskim do $1500 \mathrm{r}$. W: Ksiega jubileuszowa stulecia diecezji kieleckiej (1883-1982), Kielce 1986, s. 231-246; P. S z afra n, Rozwój średniowiecznej sieci parafialnej w Lubelszczyźnie, Lublin 1962, s. 61-65; B. K u mor, Poczatki organizacji parafialnej na ziemiach polskich. „Roczniki Teologiczno-Kanoniczne KUL" R. 5:1958 s. 103-115; J. Ta z b i row a, W sprawie badań nad geneza organizacji parafialnej w Polsce. „Przegląd Historyczny” R. 5:1963, s. 85-92.

${ }^{7}$ R. Grodecki, Iwo (Iwan lub Jan) Odroważ. W: Polski Stownik Biograficzny, t. 10, Wrocław 1962-1964, s. 187-192. 
klasztorem. Częstochowa była wówczas wsią podobną jak wiele innych w okolicy.

Dokument biskupa Iwo Odrowąża nie określał wszakże położenia miejscowości Częstochowy. W związku z tym rodzi się pytanie, gdzie znajdowała się ówczesna Częstochowa i czy faktycznie wówczas istniała druga miejscowość, noszaca nazwę Częstochówka, o której pisał ks. Jan Długosz w „Liber beneficiorum dioecesis Cracoviensis"8. Od czasu powstania dokumentu biskupa krakowskiego do chwili relacji Jana Długosza upłynęło prawie dwa i pół wieku. Rodzi się przeto uzasadnione pytanie o rozwój zaludnienia na tym terenie. Jan Długosz patrzył na te okolice w połowie XV wieku i znał ówczesną topografię tych okolic. Jednakże w ciagu dwóch i pół wieku wiele zmieniło się na tym terenie. Powstawały bowiem nowe miejscowości. Wśród nich nad Wartą powstała osada, która za czasów ojca historyków polskich przejęła rolę centralnego ośrodka na tym terenie ${ }^{9}$. Problem dotyczy tego czy Długosz w transkrypcji dokumentu biskupa Iwo Odroważa podał dosłowną wersję dokumentu czy też został podany aktualny stan osad za czasów sobie współczesnych. Według badań historyków średniowiecza coraz bardziej uzasadniona staje się teza, iż początki Częstochowy znajdowały się przy wzgórzu zwanym dawniej Stara Góra (Mons Antiquus Czanstochaw), a obecnie zwanym Jasną Górą. Według tej opinii na północnym zboczu i nieco dalej w kierunku północnym od Starej Góry znajdowała się wieś Częstochowa ${ }^{10}$. Wzgórze zaś z istniejąca tam budowlą pełniło zapewne jakieś funkcje administracyjno-obronne. Badania archeologiczne prowadzone na wzgórzu jasnogórskim wykazały, iż w miejscu dzisiejszej świątyni pod jej fundamentami znajdują się fragmenty budowli z czasów przed wybudowaniem tam świątyni, będacej kościołem parafialnym przed przybyciem paulinów. Na tym miejscu został wybudowany klasztor i świątynia paulińska. Szczegółowe badania archeologiczne w obecnej chwili są jednak niemożliwe, bowiem zagrażają bezpieczeństwu aktualnych budowli. W pobliżu dawnej budowli od strony północnej przy trakcie handlowym krakowsko-wielkopolskim leżała wieś Częstochowa ${ }^{11}$.

W późniejszym okresie w niewielkiej odległości od dotychczasowej wsi Częstochowa powstała i rozwijała się druga wieś nosząca także nazwę Czę-

${ }^{8}$ J. D lugosz, Liber beneficiorum dioecesis Cracoviensis, Wyd. A. Przeździecki, t. 3, Cracoviae 1864, s. 157-158.

${ }^{9} \mathrm{~S}$. K rak ow ski, Stara Częstochowa. Studia nad genezq, ustrojem i strukturq ludnościowa $i$ gospodarcza Częstochowy (1220-1655), Częstochowa 1948, s. 27-30.

${ }_{10}$ M. A n t o n i ew ic z, Subregion częstochowski w'średniowieczu (XIV-XV wiek). W: Częstochowa i jej miejsce w kulturze polskiej, Częstochowa 1990 s. 12-14. - Po raz pierwszy nazwa Jasna Gora wystapiła w dokumencie starosty olsztyńskiego Jerzego de Swosz z dn. 30 X 1388 r. - Zbiór dokumentów zakonu OO. Paulinów w Polsce. Opr. J. F i j a ł e k, Kraków 1938 z. 1 (1328-1464), s. 58.

${ }^{11}$ J. Go 1 o n ka, Okres przedreformacyjny. W: Jasnogórska Bogurodzica 1382-1982, Warszawa 1982, s. 33-34; S. K r a k o w s k i, Dzieje Częstochowy od wieku XII do poczqtków XIX wieku. W: Dzieje Częstochowy od zarania do czasów wspótczesnych. Pod red. S. K r akows k i g o, Katowice 1964 s. 28. 
stochowa. Była ona położona nad rzeką Wartą i wpadających doń jej dopływów. Były tam dogodne warunki dla rozwoju miejscowości. Bliskość rzeki Warty i jej dopływów były czynnikiem wybitnie sprzyjajacym rozwojowi miejscowości. Tak przeto istniały dwie miejscowości o tej samej nazwie, a ponadto znajdujące się w niedalekiej odległości. Król Kazimierz Wielki w dokumencie wystawionym w Krzepicach w dniu 24 sierpnia 1356 r. dla dwóch braci Leonarda i Kanimira przeniósł obie wsie na prawo niemieckie ${ }^{12}$. W tych okolicznościach obie wsie nosiły taką samą nazwę. Kościół parafialny pozostawał jeszcze nadal w dawniejszej Częstochowie czyli położonej wsi obok Starej Góry.

Taka sytuacja istniała najprawdopodobniej do ostatnich lat panowania króla Kazimierza Wielkiego. Za czasów króla Ludwika Węgierskiego te terytoria otrzymał jako lenno książę Władysław Opolczyk. W międzyczasie nadanie prawa niemieckiego wsi Częstochowie nad Wartą przyczyniło się do jej znacznego rozwoju. Co było powodem znacznego rozwoju wsi Częstochowa nad Warta w tym okresie? Przede wszystkim dogodne położenie nad Warta i jej dopływami. Nadto sprzyjającym czynnikiem było usytuowanie w pobliżu sławnego szlaku handlowego z Krakowa do Wielkopolski oraz drogi prowadzącej z Krakowa do Piotrkowa. Tu był punkt celny, w którym pobierano opłaty za przejazd przez rzekę Wartę. Do tego należy dodać i to, iż istniały tu lepsze gleby, występujące w pobliżu rzek i zbiorników wodnych aniżeli na terenach piaszczystych wokół zamku warownego w Olsztynie. Ten szybki rozwój Częstochowy nad rzeką Wartą spowodował to, że miejscowość ta otrzymała prawa miejskie ${ }^{13}$. Niestety dokument lokacyjny miasta Częstochowy na prawie magdeburskim wkrótce po jego wystawieniu zaginąl. W takiej sytuacji wystąpiły trudności w ustaleniu daty lokacji miejskiej dla Częstochowy nad Warta, a także wystawcy takiego dokumentu. W ostatnich latach swego panowania król Kazimierz Wielki wystawił dokumenty lokacyjne na prawie magdeburskim dla Krzepic i Przyrowa ${ }^{14}$. Ale taki dokument mógł także wystawić książę Władysław Opolczyk. Z powodu braku dokumentu lokacyjnego sprawa daty nadania praw miejskich dla Częstochowy nad Wartą oraz nazwiska jego wystawcy, przy obecnym stanie wiedzy, nie może być jednoznacznie określona. W każdym bądź razie $\mathrm{w}$ dokumencie księcia Władysława Opolczyka wystawionym w dniu 3 maja 1377 r. w Częstochowie a nadającym braciom Jaśkowi i Niczkowi nazwał Częstochowę c ivita s ${ }^{15}$. W średniowiecznych dokumentach lokacyjnych nowym jednostkom administracyjnym nadawano nazwy - civitas i oppidum. Druga nazwe otrzymywały zazwyczaj mniejsze miejscowości, natomiast miejscowości większe i mające większe znaczenie były nazywane civitas. W okolicach Częstochowy były

${ }^{12}$ Zbiór dokumentów zakonu OO. Paulinów w Polsce, Z. 1 (1328-1464). Opr. J. Fij ałe k, Kraków 1938, s. 4-6.

${ }_{13}^{3}$ S. K r a kow s k i, Stara Częstochowa, s. 31-32.

${ }^{14}$ Tamże, s. 30.

${ }^{15}$ Zbiór dokumentów zakonu OO. Paulinów w Polsce, s. 16-17. 
miasta, które otrzymały nazwę oppidum. Jakie przeto były powody nadania osadzie nad Warta praw miejskich i nazwy civitas? Dawna osada obok Starej Góry (Mons Antiquus Czenstochow) zatrzymała się na dawniejszym poziomie rozwojowym, podczas gdy osada nad Wartą stale się rozwijała ${ }^{16}$. Istotne powody nadania praw miejskich Częstochowie nad Wartą były najprawdopodobniej podane w dokumencie lokacyjnym, który już w krótkim czasie był nieznanym. Od chwili otrzymania praw miejskich Częstochowa nad Wartą otrzymała struktury miejskie - wójtostwo, radę miejska, ławę sędziowska, określone granice i pieczęć ${ }^{17}$.

Sprowadzenie paulinów z Wegier (z klasztoru Maria Nostra w Budzie) na Starą Górę, obok dawnej Częstochowy, spowodowało nowy układ kościelny $w$ tej okolicy. Dotychczas istniejąca świątynia pod wezwaniem Wniebowzięcia Najśw. Maryi Panny, będąca ośrodkiem parafialnym, została oddana $\mathrm{w}$ posiadanie 16 paulinom przybyłym $\mathrm{z}$ Węgier. Jednocześnie dla tych zakonników książę Władysław Opolczyk nakazał wybudować klasztor przy tej świątyni. Pustelniczy zakon nie sprawował wówczas czynności duszpasterskich, a udział wiernych $\mathrm{z}$ okolicznych miejscowości w nabożeństwach odprawianych w kościele klasztornym nie był zgodny z regułą zakonu paulińskiego. W tej sytuacji fundator klasztoru wystawił w dniu 21 czerwca 1382 roku dokument $\mathrm{w}$ dotychczasowym kościele potwierdzający rezygnację ówczesnego proboszcza ks. Henryka Biela z Błeszna z dotychczasowego kościoła parafialnego i swego uposażenia na rzecz przełożonego generalnego zakonu i konwentu paulińskiego. Jednocześnie dotychczasowy proboszcz przeniósł ośrodek parafialny do Nowej Częstochowy czyli miasta leżącego nad Wartą (wówczas nazwą Stara Częstochowa określano wieś położoną w pobliżu Starej Góry) ${ }^{18}$.

W powstałych okolicznościach istotnym jest pytanie o nowy kościół parafialny, bez którego nie było możliwym prowadzenie działalności parafialnej. Sądzić należy z dużą dozą prawdopodobieństwa, że w mieście Częstochowie wówczas istniał taki kościół, bowiem fundator nie wspominał o potrzebie budowy w tym miejscu nowego kościoła. Możliwym wówczas były dwa rozwiązania - albo nad Wartą już dawniej istniała świątynia albo też kościół został wybudowany dopiero w ostatnich latach. Budowa światyni po sprowadzeniu zakonników paulińskich do Starej Częstochowy była zapewne niemożliwa, bowiem budowa takiego obiektu zapewne trwała długo, zwykle kilka lat. Tuż po przybyciu zakonników do Starej Częstochowy dotychczasowy proboszcz ks. Henryk Biel przeniósł się do nowego ośrodka parafialnego, o którym dokument Opolczyka nie podaje żadnych wiadomości. Wskazuje to, że tak światynia jak i budynki kościelne już były wybudowane. Jednakże takie przypuszczenia rodzą nowe pytania o czas budowy kościoła w mie-

${ }^{16}$ E. W a rta 1 ska, dz. cyt., s. 25.

${ }^{17}$ S. K ra k ow s ki, Stara Częstochowa, s. 34; S. Ku r aś, Przywileje prawa niemieckiego miast $i$ wsi matopolskich XIV-XV wieku, Wrocław $1971 \mathrm{s.} 141 \mathrm{nn}$.

${ }^{18}$ Zbiór dokumentów zakonu OO. Paulinów w Polsce, s. 21-23. 
ście Częstochowie. Zaznaczyć wszakże należy, że podczas lokacji na prawie magdeburskim także ważnym czynnikiem było istnienie kościoła parafialnego w tym mieście. Ale taki kościół mógł być wybudowany także znacznie wcześniej niż Częstochowa otrzymała przywileje miejskie. Charakterystycznym w tej sytuacji jest wezwanie kościoła w Częstochowie nad Wartą. Kościół posiadał wezwanie św. Zygmunta, króla lotaryńskiego żyjącego na początku VI wieku. Czy nadanie takiego wezwania kościołowi mogło być dziełem mieszkańców tej miejscowości lub duchownych prowadzących pracę duszpasterska wcześniej działajacych w kościele na Starej Górze? Kult św. Zygmunta był znany w Cesarstwie Niemieckim. Wydaje się, że pomysł nadania takiego wezwania dla tej świątyni mógł wyjść jedynie od panującego na tym terenie. Wskazywałoby to, że wybór świętego króla lotaryńskiego jako wezwanie kościoła w dominium ksiażęcym był dziełem księcia Władysława Opolczyka. Książe zresztą dobrze znał sytuację istniejącą na terenie ziem niemieckich. Dla księcia zaistniała w tym czasie konieczność zorganizowania ośrodka parafialnego w mieście Częstochowa w miejsce dotychczasowego kościoła na Starej Górze pod wezwaniem Wniebowzięcia Najśw. Maryi Panny. Wobec braku dokumentu lokacyjnego można przypuszczać, że po nadaniu miejscowości Częstochowa nad Wartą lokacji miejskiej na prawie magdeburskim przez króla Kazimierza Wielkiego lub księcia Władysława Opolczyka podjęto także budowę kościoła w nowym mieście. Budowa trwała kilka lat, ale przed przybyciem paulinów w 1382 r. budowa została już ukończona i jako nowa światynia otrzymała wezwanie św. Zygmunta. Wyboru tego dokonał książę Władysław Opolczyk. Nie było bowiem innych powodów (ze strony mieszkańców miasta) aby dokonać takiego wyboru. Podobnie gdyby wcześniej już istniała ta świątynia nie było powodu, aby dokonywać zmiany dotychczasowego wezwania. W takich okolicznościach przybywał do miasta Częstochowy dawny pleban w parafii na Starej Górze w Częstochowie jako proboszcz, pełniący obowiązki duszpasterskie przy kościele parafialnym pod wezwaniem św. Zygmunta i rezydujący także przy tej świątyni ${ }^{19}$.

Ważnym dla dziejów Częstochowy jest przekaz Janka z Czarnkowa podany w jego „Kronice Polskiej 1333-1384". Dwukrotnie kronikarz za czasów króla Ludwika Węgierskiego informował o terenach, które jako lenno otrzymał książę Władysław Opolczyk. Na terenach Ziemi Wieluńskiej i okolic Częstochowy przy tej okazji wymieniał miasta i zamki, które otrzymał Opolczyk. Z racji koronacji króla Ludwika Węgierskiego na króla polskiego Janko z Czarnkowa wymienił ważniejsze miasta w tej okolicy. Informacja ta dotyczyła 1370 r. Nie było wśród tych miast Częstochowy ${ }^{20}$. Czy ten zapis

${ }^{19}$ Gdyby wcześniej istniała świątynia nad Warta, zapewne byłaby wymieniona. Książe patron parafii wybierając jako wezwanie kościoła św. Zygmunta, chciał podkreślić: zwierzchność świętego króla nad swoją książęca własnością. Księciu łatwiej było nadać kościołowi nowy tytuł niż dokonać zmiany wezwania już istniejącej świątyni. Wezwanie świątyni zależało często od właściciela posiadłości. Właściciel świątyni często jej nadawał wezwanie swego świętego patrona czyli wlasne imię.

${ }^{20} \mathrm{~J}$ anka z C zarnkow a Kronika Polska 1333-1384. W: Monumenta Poloniae Historica, t. 2, Wyd. A. Bielowski, Warszawa 1961, s. 645. 
faktycznie stwierdzał, że w tym czasie Częstochowa jeszcze nie była miastem. Zapis posiada wymowe jednoznaczna. Ale pisząc po śmierci króla Kazimierza Wielkiego kronikarz mógł nie wiedzieć o ostatnich lokacjach zmarłego monarchy. Ale także lokacji miasta mógł dokonać książę Opolczyk zaraz po przejęciu tych terenów.

Natomiast zapis z marca $1383 \mathrm{r}$. tegoż kronikarza wyraźnie podawał, że król Ludwik Węgierski oddał księciu Opolczykowi m.in. miasto Częstochowę. I znów nie jest jasną sprawą czy w chwili przekazywania Częstochowy Opolczykowi była ona miastem. Ta relacja wskazuje, że w chwili przekazywania czyli już w $1370 \mathrm{r}$. Częstochowa była miastem. W tej sytuacji należałoby uznać hipotezę, że prawa miejskie Częstochowa uzyskała już za panowania króla Kazimierza Wielkiego ${ }^{21}$.

Reasumując powyższe wywody należy stwierdzić, że w 1382 r. dawny kościół pod wezwaniem Wniebowzięcia Najśw. Maryi Panny otrzymali zakonnicy paulińscy i to wezwanie kościoła (dawniej parafialnego) pozostało nadal przy tej świątyni. Przeniesienie ośrodka parafialnego do miasta Częstochowy stało się czynnikiem powodującym dalszy rozwój tej miejscowości. W krótkim też czasie miasto znacznie przewyższyło znaczenie wsi Częstochowy spod Jasnej Góry, która w tym okresie pozostawała centrum pustelniczego zakonu paulińskiego, nie prowadzącego działalności duszpasterskiej. Wzrost znaczenia miasta Częstochowy dotyczył jedynie spraw społecznych i gospodarczych, bowiem w dziedzinie religijnej wkrótce Jasna Góra będzie zdobywać rozgłos daleko poza okolicami Częstochowy ${ }^{22}$.

Dla podjętego tematu jednak podstawowym zagadnieniem jest powstanie parafii częstochowskiej i jej rozwój, a powyższe rozważania były ważne o tyle, o ile przyczyniły się do zaistnienia tej placówki duszpasterskiej i późniejszego jej funkcjonowania.

\section{PARAFIA POD WEZWANIEM WNIEBOWZIĘCIA NAJŚWIĘTSZEJ MARYI PANNY}

$\mathrm{Na}$ początku badań dotyczących powstania parafii w Częstochowie należy zapytać o czasy zaprowadzenia chrześcijaństwa na tych terenach. Kiedy chrześcijaństwo dotarło w okolice późniejszej Częstochowy? Czy wydarzenia te nastapiły jeszcze $w$ czasach przynależności tej części ziem polskich do Księstwa Wiślan, którego granice sięgały jeszcze dalej w kierunku północnym? ${ }^{23}$ Czy chrześcijaństwo łacińskie zaprowadzone na tych terenach przez

${ }^{21}$ Tamże, t. 2, s. 735.

${ }^{22} \mathrm{~K}$. G ó rs k i, Od religijności do mistyki. Zarys dziejów życia wewnętrznego w Polsce, cz. 1 (966-1795), Lublin 1962, s. 46.

${ }^{23}$ T. L e h r-S p ła w i ńsk i, Od piętnastu wieków. Szkice z pradziejów i dziejów kultury polskiej, Warszawa 1961, s. 43; B. K u mor, Zagadnienie chrześcijaństwa metodiańskiego w Państwie Wiślan. „Zeszyty Naukowe Wydziału Humanistycznego Uniwersytetu Gdańskiego. Slawistyka" R. 3:1983, s. 47; S. S z c z u r, Misja cyrylo-metodiańska $w$ świetle najnowszych badań, W: Chrystianizacja Polski południowej. Pod red. J. M. M ał e c k i e g o, Kra- 
najstarszego syna Mieszka I, Bolesława Chrobrego, znalazło tu swój wyraz w postaci świątyni chrześcijańskiej, wystawionej na wzgórzu zwanym Stara Górą. Najwyższe wzniesienie $\mathrm{w}$ pobliżu granicy z dzielnicą Wielkopolski mogło stanowić ważny punkt strategiczny. Mogła być na nim wzniesiona strażnica wojskowa. W wyniku łacińskiej chrystianizacji prowadzonej przez Bolesława Chrobrego, popieranej także przez przyjaciela polskiego księcia biskupa praskiego św. Wojciecha Sławnikowicza, mogła tu być wzniesiona także jakaś świątynia chrześcijańska ${ }^{24}$. Niemożliwość prowadzenia badań archeologicznych pod budowlami jasnogórskimi jest przyczyną tego, że nie można dotrzeć do najdawniejszych pozostałości budowli w tym miejscu. Prawdopodobieństwo istnienia jakiejś budowli chrześcijańskiej na tym wzgórzu znalazło swój wyraz w tzw. legendzie częstochowskiej. Ludowe podanie przekazało potomności wiadomość, iż zaprzyjaźniony z Bolesławem Chrobrym, św. Wojciech po wypędzeniu go z Czech, udając się na misje do pogańskich Prusów zatrzymał się na postój w drewnianym kościółku na Starej Górze i w tym miejscu miał odśpiewać pieśń „Bogurodzicę"25. Obecnie są znane inne tłumaczenia dotyczące powstania tej pieśni kościelnej, ale i dzisiaj niektórzy badacze szukają początków „Bogurodzicy” w czasach św. Wojciecha. Nawiązując do przekazu tzw. legendy częstochowskiej należy zapytać czy było możliwym, aby św. Wojciech wędrował przez tę miejscowość. Jeżeli św. Wojciech wędrował z Czech, a takie są wyniki badań badaczy tego problemu, to najłatwiej było mu podróżować drogą krakowska, która właśnie prowadziła w pobliżu Starej Góry, a w takich okolicznościach mógł zarządzić postój na wzgórzu częstochowskim. Byłoby to prawdopodobne i dlatego, iż w niedalekiej odległości musiał przekraczać granice terytorium od dawna należącego do Bolesława Chrobrego i będącego jednocześnie pod jurysdykcją biskupa praskiego. Za rzeką Liswartą w kierunku północnym była już dzielnica Wielkopolska ${ }^{26}$.

Dokument wydany przez biskupa krakowskiego Iwo Odrowąża nie wymieniał wszakże kościoła w Częstochowie. Biskup jedynie zatwierdzał dziesięciny dla klasztoru Kanoników Regularnych we Mstowie, nadane przez jego poprzedników. Według relacji podanej przez Jana Długosza dziesięciny mieli składać mieszkańcy Częstochowy i Częstochówki. Nazwa wsi Częstochówka jednakże była znana dopiero w czasach Długosza, a w dokumencie

ków 1994, s. 17-18; J. W y rozu m s k i, Zagadnienie poczq̨tów biskupstwa krakowskiego, W: Chrystianizacja Polski potudniowej, s. 121-123; H. Ło m i ń ski, Poczatki Polski. $Z$ dziejów Stowian w I tysiqcleciu n.e., t. 4, Warszawa 1970, s. 299 nn.; W. S z a frán s k i,

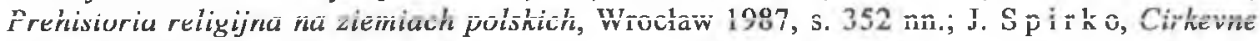
dejiny, t. 2, Bratysława 1996, s. 231.

${ }^{24}$ A. B a r c i a k, Chrystianizacja Czech w obrzqdku tacińskim. W: Chrystianizacja Polski poludniowej, s. 28-29.

${ }_{25}$ J. Mikołajtis, J. Łączewski, R. Karpowicz, $Z$ dziejów Częstochowy. W: Zapisy dziatalności literackiej w Czestochowie. Pod red. Z. J. Mikołajt is a i A. B aran o w s k i e g o, Częstochowa 1972, s. 3-4.

${ }^{26}$ S. K rakow k i, Stara Częstochowa, s. 30; J. Z w i ąze k, Przynależność kościelna pogranicza Wielko- i Matopolski ze Ślaskiem, s. 34-35. 
biskupa Iwo Odrowąża nie występowała. Zresztą sprawa występowania nazw miejscowości Częstochowa i Częstochówka w średniowieczu posiada już swoją literaturę ${ }^{27}$. Natomiast $w$ dokumencie biskupa Odrowąża ważnym jest stwierdzenie, że Częstochowa była wsią składającą dziesięcinę. Wywody prof. Stefana Krakowskiego jednoznacznie wykazały, że w XIII wieku Częstochowa jeszcze parafią nie była ${ }^{28}$. Jednakże przed $1325 \mathrm{r}$. musiały wystapić jakieś okoliczności, które doprowadziły do powstania parafii w tej miejscowości z ośrodkiem przy kościele na Starej Górze. Co mogło spowodować, że powstała parafia w Częstochowie. Otóż dotychczas istniała parafia we Mstowie, do której według pojęcia parafii średniowiecznej należała również wieś Częstochowa. Z drugiej strony Częstochowy w kierunku zachodnim istniał ośrodek parafialny w Kłobucku. Na przestrzeni ponad $30 \mathrm{~km}$ nie było żadnego ośrodka parafialnego, a tymczasem według pojęć średniowiecznych ówczesna Częstochowa była znacznym skupiskiem ludności. Według tradycji przekazanej w tzw. legendzie częstochowskiej oraz szczątkowych wykopalisk archeologicznych na Starej Górze w pobliżu Częstochowy istniał kościół. Taki kościół drewniany istniał $w$ chwili sprowadzenia zakonników paulińskich. To ten kościół był ośrodkiem parafii, założonej przez któregoś z następców biskupa Iwo Odrowąża.

Pierwsza wiadomość o parafii częstochowskiej została podana w wykazach świętopietrza z 1325 roku. W tym roku w wykazie świętopietrza z dekanatu Irządze (Idzranza) odnotowano: „Item Bogufalus, plebanus ecclesie de Czanstacowa, de 1 marc, similiter solvit 1 scot cum dim (midio). Item in secundo termino nichil (sic) solvit. Summa: 1 scot. cum dim"29. Wymienienie w wykazie świętopietrza w 1325 r. plebana Bogufała przy kościele w Częstochowie oznaczało, że wówczas istniała już pełnoprawna parafia w Częstochowie. Niestety na jego podstawie nie można określić daty powstania tej parafii.

Podobnie późniejsze wykazy świętopietrza regularnie wymieniały od 1335 r. parafię częstochowską (Zanthicova), która na ten cel płaciła sumę 3 skojców. Ta stała wielkość składanego świętopietrza za czasów króla Kazimierza Wielkiego oznaczała, że taksy świętopietrza były ustalone dla określonych wielkości parafii, a niewielkie różnice w liczbie wiernych nie powodowały zmiany wysokości świętopietrza, płaconego z tej parafii. Nie ulegająca zmianie składka na opłaty świętopietrza $\mathrm{z}$ parafii częstochowskiej wskazywała jednocześnie, że jej rozwój ludnościowy postępował powoli i dlatego wysokość świętopietrza pozostawała na tym samym poziomie ${ }^{30}$.

${ }^{27}$ M. Antoniewi cz, Subregion częstochowski..., s. 11; Stownik historyczno-geograficzny województwa krakowskiego $w$ średniowieczu. Opr. Z. Leszczyńska-Skrętow a, F. S i k or a, cz. 1, Wrocław 1985, z. 3, s. 471.

${ }^{28} \mathrm{~S}$. K r a k ow s k i, Stara Czestochowa, s. 25.

${ }^{29}$ Acta Camerae Apostolicae, vol. I (1207-1344). Wyd. J. P taśn i k. W: Monumenta Poloniae Vaticana, t. 1, Cracoviae 1913, s. 139.

${ }^{30}$ T. G ro m n i c k i, Świętopietrze w Polsce, Kraków 1908, s. 352-353. 
Według obliczeń Tadeusza Landenbergera liczba mieszkańców parafii częstochowskiej w I połowie XIV wieku wynosiła zaledwie 144 osoby. W tym samym czasie na terenie archidiecezji gnieźnieńskiej parafia Borzykowa liczyła 864 wiernych, a parafia Kurzelów posiadała 768 wiernych $^{31}$. Jednakże do tak małej liczby wiernych na terenie parafii częstochowskiej krytycznie odniósł się prof. Krakowski twierdząc, że w tym czasie liczba wiernych w parafii znacznie powiększyła się nie tylko w Częstochowie obok Starej Góry, ale także w Częstochowie nad Wartą, a także dzięki przyłączeniu do parafii wsi Konopiska, Grabówka i Wyczerpy ${ }^{32}$.

Jak wyżej już podano tak Częstochowa leżąca u podnóża Starej Góry, jak i Częstochowa nad Wartą były wsiami, które król Kazimierz Wielki w dniu 24 VIII 1356 r. obdarował przywilejami prawa niemieckiego. Parafia nadal istniała przy kościele pod wezwaniem Wniebowzięcia Najśw. Maryi Panny na Starej Górze. I taka sytuacja utrzymała się najprawdopodobniej do końca panowania króla Kazimierza Wielkiego. Zmiany w strukturze parafialnej nastapiły z chwilą powstania klasztoru paulińskiego przy dawnym kościele parafialnym pod wezwaniem Wniebowzięcia NMP.

\section{PARAFIA POD WEZWANIEM ŚW. ZYGMUNTA}

Decyzje jakie podjął książę Władysław Opolczyk ulokowały ośrodek parafii częstochowskiej w niedawno powstałym mieście Częstochowie, leżącym nad Warta, a parafia otrzymała nowe wezwanie św. Zygmunta. Na takie zmiany wyraził zgode biskup krakowski Jan Radlica, bowiem w granicach jego diecezji leżała Częstochowa. Biskup musiał posiadać ważne powody, aby dokonać zmiany wezwania parafii. Przyczyną tych zmian była prośba księcia Władysława Opolczyka, fundatora klasztoru paulińskiego.

Istotnym elementem do powstania $\mathrm{i}$ funkcjonowania parafii $\mathrm{w}$ końcu XIV stulecia należało określenie jej terytorium. O ile jednak $w$ okresie wprowadzania chrześcijaństwa na ziemie polskie było rzeczą niemożliwą określenie granic parafii, a nawet diecezji, to w XIV w. granice były już określone. Z powodu przeniesienia ośrodka parafii częstochowskiej ze Starej Góry nad Wartę i dokonanej zmiany wezwania parafii z Wniebowzięcia Najśw. Maryi Panny na św. Zygmunta granice parafii nie uległy zmianie. Na wielkość terytorium parafii znaczny wpływ posiadały przynajmniej dwa czynniki - odległość od kościoła parafialnego oraz przynależność określonych miejscowości do własności rodów szlacheckich. Szlachcic posiadający własny kościół (ecclesiam propriam) wyznaczał dla niego uposażenie ze swoich posiadłości. W tych warunkach zdarzały się wypadki, że wierni mający blisko do kościoła parafialnego w innej parafii, należeli faktycznie do tej parafii, w której ius patronatus sprawował dziedzic ich miejscowości, mimo

${ }^{31}$ T. Lad enberger, Zaludnienie Polski na początku panowania Kazimierza Wielkiego, Lwów 1930, s. 82-83.

${ }_{32}$ S. K r a k ow sk i, Stara Częstochowa, s. 26-27. 
że kościół parafialny był w dużej odległości. Po przyłączeniu lenna księcia Władysława Opolczyka do Królestwa Polskiego przez króla Władysława Jagiełłę Częstochowa była królewszczyzną (miasto). Miasto Częstochowa leżało w odległości kilkunastu km od Olsztyna, w którym był potężny zamek obronny, ale podgrodzie rozwijało się bardzo wolno. W okolicy nie było wielkich posiadłości szlacheckich, a mniejsze posiadłości szlacheckie grawitowały ku Częstochowie. Natomiast tak do Mstowa, jak i Kłobucka, w których istniały kościoły parafialne było zbyt daleko. Zaludnienie w tym czasie było słabe. Przyjąć przeto należy, że do kościoła parafialnego w mieście Częstochowa przybywali wierni $\mathrm{z}$ okolicznych miejscowości, położonych w odległości ok. $10 \mathrm{~km}$ od kościoła parafialnego. Jedynie od strony północno-zachodniej rozciągały się posiadłości Nekandów-Trepków, którzy w miejscowości Białej posiadali ecclesiam propriam, dla której określali uposażenie.

Dopiero w „Liber beneficiorum diosecesis Cracoviensis” Jan Długosz podał opis parafii częstochowskiej pod wezwaniem św. Zygmunta. Nie wspomniał jednak w tym miejscu o dawnej parafii pod wezwaniem Wniebowzięcia Najśw. Maryi Panny. Tak jak dawniej parafia należała do dekanatu lelowskiego, wcześniej zwanym irządzkim. W tym dekanacie parafia częstochowska była na północno-zachodnich jego krańcach (dalej w kierunku zachodnim były parafie Kłobuck i Krzepice). Długosz podał, że w mieście był kościół pod wezwaniem św. Zygmunta. Podkreślił także, że parafia była własnością klasztoru jasnogórskiego (monasterio Częstochoviensi incorporata), czyli klasztor jasnogórski sprawował ius patronatus nad ta parafia ${ }^{33}$. Stwierdzenie, że kościół parafialny i parafia były inkorporowane klasztorowi częstochowskiemu posiadało duże znaczenie. W tym bowiem czasie, w $1474 \mathrm{r}$. proboszcz parafii św. Zygmunta w Częstochowie ks. Piotr z Chorzenic, kapłan diecezjalny, za zgodą biskupa krakowskiego Jana Rzeszowskiego, przekazał duszpasterstwo $w$ tej parafii paulinom jasnogórskim. Jednocześnie paulini ufundowali przy kościele św. Zygmunta nowy klasztor, w budynkach plebańskich, który pełnił jednocześnie funkcję plebani parafialnej. Fakt iż klasztor jasnogórski sprawował ius patronatus nad parafią częstochowską był okolicznością bardzo korzystną. Patron parafii, czyli klasztor pauliński na Jasnej Górze, będący w bezpośredniej bliskości i jednocześnie zainteresowany należytym funkcjonowaniem parafii, zapewniał parafii i świątyni parafialnej odpowiednie warunki materialne oraz opiekę duszpasterską. Przełożeni paulińscy z klasztoru jasnogórskiego nie tylko wyznaczali zakonników do stałej pracy parafialnej, ale także w czasie natężonej działalności duszpasterskiej wyznaczali dodatkowych zakonników do pomocy w pracy parafialnej. W nowych warunkach kościelnych w parafii częstochowskiej zaistniała jeszcze jedna korzystna okoliczność dla należytego wypełniania praktyk religijnych przez wiernych. Kościół pod wezwaniem św. Zygmunta był niewielkim obiektem sakralnym, w którym w nabożeństwach mogła uczestniczyć jedno-

${ }^{33} \mathrm{~J}$. D ł u g o s z, Liber beneficiorum dioecesis Cracoviensis. Wyd. A. P r z eźd z i e c k i, t. 2, Cracoviae 1864, s. 220. 
cześnie niewielka część parafian. W tej sytuacji klasztor jasnogórski dla potrzeb parafian częstochowskich udostępnił swoje kościoły i kaplice na terenie miasta Częstochowy i wsi Częstochowy, którą Długosz nazywał Częstochówką. Wypełnianie praktyk religijnych przez wiernych w tych świątyniach paulińskich posiadało taki sam walor, jakby były wykonywane w kościele parafialnym (np. spowiedź wielkanocna). Dla wzrastającej liczby wiernych $\mathrm{w}$ parafii miało to istotne znaczenie. Przeto w świątyniach paulińskich - na Jasnej Górze, św. Barbary, św. Jakuba, św. Rocha i Sebastiana na cmentarzu grzebalnym oraz Pana Jezusa Konającego okoliczni wierni mogli wypełniać swoje powinności religijne. Pod tym względem parafia posiadała doskonałe warunki $w$ realizacji pracy duszpasterskiej. Taka sytuacja istniała wszakże w późniejszych czasach, kiedy liczba parafian znacznie wzrosła. Nadzór klasztoru jasnogórskiego wynikający $\mathrm{z}$ ius patronatus zapewniał też odpowiednie warunki materialne dla świątyni, szczególnie wówczas kiedy trzeba było odpowiednio uposażyć lub przeprowadzać remonty świątyni. Podobnie pomoc zakonników jasnogórskich w pracy parafialnej i przywilej korzystania ze świątyń paulińskich zapewniał dogodne warunki dla wypełniania praktyk religijnych wiernym ${ }^{34}$.

Za czasów Jana Długosza oprócz miasta Częstochowy do parafii częstochowskiej należały także okoliczne wsie - Konopiska będące własnością Jakuba z Koniecpola, Rększowice stanowiące własność króla polskiego, podobnie Dźbów był królewszczyzna, zaś wsie Wrzosowa i Błeszno należały do dóbr dziedzicznych Jakuba Trepki, natomiast położone w północnej części parafii wsie Kiedrzyn i Wierzchowiska były królewszczyznami. Jednakże dla kilku wsi - Wyczerpy, Krowodrza (Kawodrza) i Grabówka nie podał Długosz właścicieli. Ostatnią wsią należącą do parafii była Częstochówka, która stanowiła własność klasztoru jasnogórskiego. Charakterystyczna była nazwa wsi Częstochówki. Ta nazwa jedynie odróżniała wieś od miasta Częstochowy. Dodać wszakże trzeba, że liczba mieszkańców miasta znacznie przewyższała liczbę mieszkańców wsi Częstochowy. W okolicach Częstochowy, Długosza interesowały także kopalnie rudy żelaza i kuźnice. Określał je jako fabrica ferri. Takie kuźnice istniały w Błesznie i w Gnaszynie (Gweschyn). Fabrica ferri w Błesznie (Blyeschno) stanowiła własność prywatna, a kuźnica w Gnaszynie była własnością klasztoru jasnogórskiego. Określone w ten sposób w „Liber beneficiorum" terytorium świadczyło o rozległości tej parafii. Jak $\mathrm{z}$ powyższego opisu wynika, terytorium parafii rozciagało się głównie w kierunku południowo-zachodnim od miasta Częstochowy i klasztoru jasnogórskiego ${ }^{35}$.

W następnych latach terytorıum paratii częstochowskiej nie ulegało zasadniczym zmianom. Nadal pozostawała ta sama światynia parafialna. Parafia należała do sławnego klasztoru i zakonu paulińskiego, a jej terytorium ani

${ }^{34}$ Jednocześnie król Kazimierz Jagiellończyk zrzekł się ius patronatus nad parafią częstochowska, a oddał ją paulinom jasnogórskim. - S. Krak ow ski, Dzieje Częstochowy od wieku XII do poczatków XIX, s. 40.

${ }^{35}$ J. D 1 u g o s z, Liber beneficiorum..., t. 2, s. 221, 
nie było powiększone ani pomniejszone, bowiem każda zmiana terytorialna wymagała specjalnego pozwolenia biskupa krakowskiego. Jedynie w odległej wsi Konopiska (ok. $15 \mathrm{~km}$ ) została utworzona filia macierzystego kościoła, przeznaczona dla miejscowych wiernych. Przy istniejącej tam kaplicy mieszkał na stałe zakonnik - filialista, a w wypadkach, kiedy występowało nasilenie pracy duszpasterskiej przybywali mu z pomoca zakonnicy z klasztoru jasnogórskiego. Filia w Konopiskach stanowiła integralną część parafii częstochowskiej. Nie zmieniała się także liczba duchownych prowadzących pracę parafialną. Zwykle był tutaj proboszcz i dwóch wikariuszy, wyznaczonych przez przełożonych klasztoru jasnogórskiego, a zatwierdzonych przez władzę diecezji krakowskiej ${ }^{36}$.

W czasie wizytacji przeprowadzonej przez archidiakona ks. Krzysztofa Kazimirskiego z polecenia biskupa krakowskiego kardynała Jerzego Radziwiłła w 1598 r. w granicach parafii oprócz miasta Częstochowy były następujące wsie: Częstochówka, Dźbów, Gnaszyn, Grabówka, Kiedrzyn, Konopiska, Kawodrza, Rększowice, Wierzchowiska, Wrzosowa, Błeszno, Wyczerpy, Kuźnica Dźbowska, Wola Hankowska, Kamień i Nowa Wieś (włączona w 1606 r. do parafii Poczesna) $)^{37}$. Natomiast bardzo ważna była informacja podana przez Kazimirskiego o istnieniu w parafii częstochowskiej szkoły parafialnej. Wizytator stwierdzał, że budynek szkolny był w dobrym stanie, kierownikiem szkoły był Mateusz z Prasnysza, którego utrzymywał przeor pauliński, miejscowy proboszcz. Rektor szkoły otrzymywał pensję w wysokości 4 zł 24 groszy, W dekrecie reformacyjnym wizytator polecil, aby uczniowie tej szkoły recytowali w każdą niedzielę w kościele parafialnym katechizm ${ }^{38}$. Natomiast w czasie wizytacji przeprowadzonej za czasów biskupa Bernarda Maciejowskiego w budynku szkolnym mieszkał bakałarz Jan Dyszel, któremu pensję wypłacał konwent paulinów i urząd miejski. Proboszcz nadto dawał nauczycielowi codziennie obiad. Wizytator także podtrzymał zalecenie, aby scholarzy w niedziele w kościele recytowali katechizm ${ }^{39}$.

Zachowały się dokładne dane na temat stanu parafii częstochowskiej z końca XVIII wieku. Najpierw przeprowadził spis ludności w parafiach na terenie diecezji krakowskiej biskup krakowski Kajetan Ignacy Sołtyk w 1763 r. Na terenie parafii mieszkało wówczas 3621 katolików przystępujących do Komunii św. wielkanocnej, w parafii było 237 chrztów, 66 ślubów i 123 pogrzeby. Mieszkało także 30 Żydów. Nie podano jednak pełnej liczby mieszkańców na terenie parafii. Przyjmując przeto szacunkowo, iż dzieci oraz chorzy i starcy stanowili czwartą część ogółu wiernych można przyjąć, że liczba wszystkich mieszkańców w parafii wynosiła ok. 4500 wiernych. Równie

${ }^{36}$ H. K o ła w s k i, Konopiska. Szkic monograficzny. „Kronika Diecezji Kujawsko-Kaliskiej" R. 11:1917, s. 178.

${ }^{37}$ (Bez sygn.): Archiwum Parafii św. Zygmunta w Częstochowie, Protokót z wizyty biskupiej w 1598 roku zaszłej, Protokoły z wizyt biskupich oraz inwentarz z lat 1598-1866. (brak paginacji).

\footnotetext{
${ }^{38} \mathrm{~S}$. K o t, Szkolnictwo parafialne w Małopolsce XVI-XVIII w. Lwów 1912, s. 201.

39 Tamże, s. 201.
} 
szczegółowy wykaz mieszkańców podała wizytacja przeprowadzona z nakazu tegoż biskupa w dniu 25 I 1781 r., ale zapewne przy współudziale biskupa koadiutora Michała Poniatowskiego. Od następnego roku biskup Poniatowski już osobiście kierował diecezją krakowską. Przeprowadzony z jego polecenia spis ludności w 1782 r. podał, że parafia częstochowska liczyła 6000 katolików, ale nadto w filii Konopiska było ok. 2000 wiernych. W kościele parafialnym do Komunii św. wielkanocnej przystapiło 4519 wiernych, a w Konopiskach 1060 wiernych, w parafii było 325 chrztów i 58 chrztów w Konopiskach, w parafii były 63 śluby i w Konopiskach 13 ślubów oraz 215 pogrzebów w parafii i 44 pogrzeby w Konopiskach. Na terenie parafii mieszkało 80 Żydów (w Konopiskach nie było Żydów) ${ }^{40}$.

Najbardziej szczegółowy spis ludności w diecezji krakowskiej został przeprowadzony z nakazu biskupa Poniatowskiego w 1787 r. Biskup podawał nawet schemat prowadzonego spisu. Mieli go przeprowadzić miejscowi proboszczowie do końca miesiąca kwietnia $1787 \mathrm{r}$. Były to więc najbardziej aktualne dane o stanie wiernych w parafiach. Na podstawie przesłanych danych zebranych przez proboszczów dopiero ks. dr Marcin Siemieński ${ }^{41}$, pisarz sądów biskupich zadwornych w Krakowie dokonał obliczeń dla całej diecezji. Według tego spisu ludności w parafii częstochowskiej było 4543 katolików oraz w filii w Konopiskach 1673 wiernych $^{42}$.

Granice parafii częstochowskiej w tym czasie wyznaczały miejscowości - od strony wschodniej Wyczerpy i Mirów, od strony południowej Konopiska (filia), od strony zachodniej Kawodrza i Lojki i od strony północnej Kiedrzyn i Wierzchowiska. Dodać nadto należy, że w tym czasie w mieście Częstochowie miejscowi Żydzi nie posiadali własnej gminy żydowskiej zwanej kahałem, a na nabożeństwa chodzili do synagogi w Janowie k. Częstochowy.

C.D.N.

${ }^{40}$ B. K u mo r, Spis ludności diecezji krakowskiej prymasa M. J. Poniatowskiego z 1787 roku. „Archiwa, Biblioteki i Muzea Kościelne” t. 35:1977, s. 270.

${ }_{41}$ J. Z wi ąze k, Siemieński Marcin. W: Polski Słownik Biograficzny, t. 37, Kraków 1996, s. 30-31.

${ }^{42}$ B. K u m or, Spis ludności... prymasa M. J. Poniatowskiego..., s. 281. 